\title{
Commentary \\ Intensive glycemic control in traumatic brain injury: what is the ideal glucose range?
}

\author{
Paul M Vespa
}

Departments of Neurosurgery and Neurology, David Geffen School of Medicine at UCLA, 757 Westwood Blvd, Suite 6236A, Los Angeles, CA 90095, USA

Corresponding author: Paul M Vespa,Pvespa@mednet.ucla.edu

Published: 1 September 2008

This article is online at http://ccforum.com/content/12/5/175

(c) 2008 BioMed Central Ltd

See related research by Meier et al., http://ccforum.com/content/12/4/R98
Critical Care 2008, 12:175 (doi:10.1186/cc6986)

that intensive glycemic control resulted in less neurologic complications.

The most recent medical intensive care unit study of intensive glycemic control was less convincing [8]. In the latter study, mortality was not reduced in the overall intention-to-treat group, and a very small positive effect of intensive glycemic control on mortality was seen in patients treated for $>3$ days. At the same time, there remains some concern that intensive glycemic control (4.4 to $6.1 \mathrm{mmol} / \mathrm{l}$ ) is not appropriate for brain-injured patients, and may elicit secondary injury [9]. Using cerebral microdialysis in brain-injured patients, Vespa and colleagues found that the infusion of insulin to achieve intensive glycemic control resulted in profound reductions of brain glucose and in elevation of biomarkers indicating cellular distress - namely glutamate and lactate/pyruvate ratio. This finding has been replicated in patients with subarachnoid hemorrhage [10], in which patients with intensive glycemic control have elevated microdialysis glycerol and elevated lactate/pyruvate. In addition, there is evidence that moderate hyperglycemia (12 to $15 \mathrm{mmol} / \mathrm{l}$ ) is not associated with adverse events after brain injury [11].

A small single-center randomized trial comparing intensive glycemic control with moderate hyperglycemia in subarachnoid hemorrhage patients recently failed to demonstrate a benefit on mortality or vasospasm ischemic insults [12]. There is therefore great uncertainty about how best to control systemic glycemia after brain injury.

It is in this context that we consider the recent paper of Meier and colleagues [1]. In this paper, Meier and colleagues performed a retrospective study comparing the incidence of hypoglycemia and other adverse consequences when intensive glycemic control (goal of 3.5 to $6.5 \mathrm{mmol} / \mathrm{l}$ ) was used versus when loose glycemic control (goal of 5 to $8 \mathrm{mmol} / \mathrm{l}$ ) was used. The results are complex and do not indicate that results indicated convincingly that intensive glycemic control was beneficial, and subsequent post-hoc analysis indicated 
intensive glycemic control is beneficial overall. Specifically, the authors report that the incidence of hypoglycemia and intracranial hypertension is higher in those patients undergoing intensive glycemic control during the initial week after injury, and that the rate of bacteremia is higher and urinary tract infections are worse too. While there was a trend towards a better intracranial pressure profile during the second week after injury in the intensive control group, the preponderance of data points against the use of intensive glycemic control. This finding stands in sharp contrast to the results of Van Den Berghe and colleagues [8], in which the incidence of intracranial hypertension and of mean intracranial pressure was less in the group undergoing intensive glycemic control. Moreover, Meier and colleagues report a trend towards worsened survival at 21 days after brain injury in the intensive glycemic control group. This unexpected worsening of mortality is cause for great concern among those who advocate intensive glycemic control in brain trauma.

The stage is clearly set for prospective study of glycemic control. In our center we have begun to use cerebral microdialysis and positron emission tomography to prospectively identify the ideal lowest glycemic range that appears to be safe from the brain's metabolic perspective. The operational definition of a lowest safe glycemic range may not be uniform among patients, and is as yet unclear. The lowest safe glycemic range will probably be defined by the serum glucose value that does not elicit metabolic disturbance in the brain, as measured by sophisticated brain monitors such as microdialysis and positron emission tomography.

Once the lowest safe glycemic range is identified, a multicenter randomized control trial will be needed to determine whether some form of glycemic control is better than moderate hyperglycemia for brain-injured patients. For now given the cumulative evidence that intensive glycemic control is associated with metabolic distress [9], with increased hypoglycemia, with worsened intracranial pressure, and with worsened mortality [1] - the ideal range for glycemic control is unclear.

\section{Competing interests}

PMV receives funding on the subject of glycemic control.

\section{References}

1. Meier R, Béchir M, Ludwig S, Sommerfeld J, Keel M, Steiger P, Stocker R, Stover JF: Differential temporal profile of lowered blood glucose levels ( 3.5 to $6.5 \mathrm{mmol} / \mathrm{I}$ versus 5 to $8 \mathrm{mmol} / \mathrm{l}$ ) in patients with severe traumatic brain injury. Crit Care 2008, 12:R98.

2. Lam AM, Winn HR, Cullen BF, Sundling N: Hyperglycemia and neurological outcome in patients with head injury. $J$ Neurosurg 1991, 754:545-551.

3. Cochran A, Scaife ER, Hansen KW, Downey EC: Hyperglycemia and outcomes from pediatric traumatic brain injury. J Trauma 2003, 55:1035-1038.

4. De Salles AA, Muizelaar JP, Young HF: Hyperglycemia, cerebrospinal fluid lactic acidosis, and cerebral blood flow in severely headinjured patients. Neurosurgery 1987, 21:45-50.

5. Rovlias A, Kotsou S: The influence of hyperglycemia on neuro- logical outcome in patients with severe head injury. Neurosurgery 2000, 46:335-342.

6. Van den Berghe G, Wouters P, Weekers F, Verwaest C, Bruyninckx F, Schetz M, Vlasselaers D, Ferdinande $P$, Lauwers $P$, Bouillon $\mathrm{R}$ : Intensive insulin therapy in the critically ill patients. N Engl J Med 2001, 345:1359-1367.

7. Van den Berghe G, Schoonheydt K, Becx P, Bruyninckx F, Wouters $\mathrm{PJ}$ : Insulin therapy protects the central and peripheral nervous system of intensive care patients. Neurology 2005, 64:1348-1353.

8. Van den Berghe G, Wilmer A, Hermans G, Meersseman W, Wouters PJ, Milants I, Van Wijngaerden E, Bobbaers H, Bouillon $\mathrm{R}$ : Intensive insulin therapy in the medical ICU. N Engl J Med 2006, 354:449-461.

9. Vespa $\mathrm{P}$, Boonyaputthikul $\mathrm{P}$, McArthur DL, Miller C, Etchepare M, Bergsneider M, Glenn T, Martin NA, Hovda DA: Intensive insulin therapy reduces microdialysis glucose values without altering glucose utilization or improving the lactate/pyruvate ratio after traumatic brain injury. Crit Care Med 2006, 34:850-856.

10. Schlenk F, Graetz D, Nagel A, Schmidt M, Sarrafzadeh AS: Insulin-related decrease in cerebral glucose despite normoglycemia in aneurysmal subarachnoid hemorrhage. Crit Care 2008, 12:R9.

11. Zygun DA, Steiner LA, Johnston AJ, Hutchinson PJ, AIRawi PG, Chatfield D, Kirkpatrick PJ, Menon DK, Gupta AK: Hyperglycemia and brain tissue $\mathrm{pH}$ after traumatic brain injury. Neurosurgery 2004, 55:877-881.

12. Bilotta F, Spinelli A, Giovannini F, Doronzio A, Delfini R, Rosa G: The effect of intensive insulin therapy on infection rate, vasospasm, neurologic outcome, and mortality in neurointensive care unit after intracranial aneurysm clipping in patients with acute subarachnoid hemorrhage: a randomized prospective pilot trial. J Neurosurg Anesthesiol 2007, 19:156-160. 